increased, so that after the necessary period, which varies according to the description and thickness of wood, whether fractious or kindly, the chamber may be opened and the charge will be found to conform to any given degree of moisture contents stipulated. Complete reliance can be placed on either of these methods.

The outlay required to provide an adequate number of such kilns throughout Great Britain will, of course, be heavy, but having regard to the urgency, this consideration ought to be of secondary importance.

An ample supply of properly seasoned timber for the boxing and safe transport of the vital necessities of war is essential to our war effort, and until this question has been adequately dealt with we may suffer serious losses, not only financial but also endangering the health and welfare of our troops and those of our Allies.

\section{NEW AND LITTLE-KNOWN FISHES}

$\mathrm{T}$ THE Stanford Ichthyological Bulletin, published by the Natural History Museum of Stanford University, is responsible for many valuable descriptions of fishes, and the two numbers before us (2, No. 4, Aug. 24, No. 5, Aug. 31, 1942) contain various papers, the most striking of which are George G. Myers's "Studies of South American Freshwater Fishes" and Albert W. C. T. Herre's "New and Little Known Phallostethids, with Keys to the Genera and Philippine Species". The Natural History Museum of Stanford University has amassed a large collection of South American fishes, which, together with the very extensive South American material in the California Academy of Science, forms probably the finest series available anywhere for the study of South American fluviatile ichthyology.

In the present work are included fishes from Amazonian Peru, from Venezuela and from Rio de Janeiro. Especially interesting is Hoplomyzon atrizona n.g. et sp., a new Bunocephalid from Peru, which is armed with a series of bony plates along the body, and apparently has no close relatives. It is adapted for life in swift water and the head has maxillary barbels strongly resembling some of the hill-stream Nematognaths.

Many new Cyprinodonts were collected by Lieut.Col. and Mrs. White in the coastal plain of the State of Rio de Janeiro, their object being to study them in their own aquaria. Fishes of the genus Cynolebias are favourites with aquarists and are known to be annual fishes with a full life-cycle within one year. They are usually found in isolated water holes, swamps and ponds which dry up in the dry season, only the eggs surviving in the mud. After hatching in the wet season, development of the fry is rapid and in some instances full growth is attained in two or three months. The species of this genus, owing to their specialized habitat and seasonal occurrence, are seldom seen by ordinary ichthyologists and are usually only obtained through commercial aquarium fish collectors. The present series is therefore specially valuable. It includes many new forms of these very beautiful small fishes which in life are brilliantly coloured. Five of the new species are described and notes given from colour sketches made from the living material.

Herre's paper on the Phallostethids describes many of these peculiar fishes, which are all very small and almost transparent with very little colouring. The sexes are strongly dimorphic, the male possessing a special bony organ lying on the outside of the head which serves for clasping the female. Eighteen species are so far known, occurring in brackish and salt water in Malaya, Singapore, Siam, Borneo and the Philippines, in mountain brooks in Luzon and lowland freshwater creeks in Siam and Luzon, and in freshwater lakes from the Philippines and off Sumatra. It is expected that many more are yet to be discovered.

\section{SCOTTISH LAKE DWELLINGS*}

$\mathrm{F}$

OR the first time one of the very numerous artificial islands on the Scottish lochs has been examined with a technical skill comparable to that so profitably expended on the crannogs of Somerset and more recently of Ireland. Fortunately, the engineers in charge of the Lochaber Water Power Scheme appreciated the scientific importance of the crannog in the north end of Loch Treig that the scheme had exposed and would destroy. Still more fortunately Prof. Ritchie, then at the University of Aberdeen, was able to take advantage of the opportunity for a thorough investigation of the island's structure.

The crannog proved to differ both in plan and construction from the Glastonbury lake village and the individual laeustrine habitations explored by Munro in Galloway last century and more recently by Hencken in Ireland. While the latter are round, it was rectangular. The basal structure was a framework of squared beams, $65 \mathrm{ft}$. by $42 \mathrm{ft}$., founded upon a bed of large stones that had been laid on a natural elevation in the loch floor. Above this, layers of timbers and of earth and stones, each separated by layers of brushwood, birch-branches or heather, and in all nearly $6 \mathrm{ft}$. thick, supported an upper framework of undressed trunks $57 \mathrm{ft}$. Iong by $30 \mathrm{ft}$. broad. It supported yet another layer of brushwood, above which came the actual dwelling floors, frequently renewed until the total deposit above the upper platform was $3 \mathrm{ft}$. thick. The timber frameworks were kept in place by a double row of upright piles that the excavator shows cannot have served as a defensive palisade.

Access to the island was not provided by any causeway, but a landing stage was found from which a sloping ladder led up to the island's surface. The report emphasizes the structural importance of the brushwork layers both in distributing the weight of superstructures and in cementing together heterogeneous layers.

Ritchie argues convincingly that the usual accounts of the construction of such islands simply will not work with the Treig crannog, and concludes that its builders must have temporarily lowered the waterlevel at this end of the loch. Relics were disappointingly scarce. They confirm literary testimony to the occupation of the island in the sixteenth and seventeenth centuries, but nothing unambiguously distinctive of an earlier period was found, though a leather shoe seems to be derived from a RomanoBritish pattern, and the peculiar technique exemplified in a woollen fabric finds its nearest (but still not exact) parallel in textiles of the Viking Age.

* "The Lake-dwelling or Crannog in Eadarloch, Loch Treig: its Antiquaries Scot., 76, 8-78, with plates IV-XIX and 22 text-figures. 